\title{
Penuntasan Wajib Belajar 12 Tahun di Provinsi DKI Jakarta
}

\author{
Muhamad Husin \\ Guru SMA Negeri 111 Jakarta, e-mail: husin_111@yahoo.com
}

\begin{abstract}
Abstrak: Program wajib belajar sembilan tahun pendidikan di Indonesia mulai dicanangkan pada tahun 1994 dan ditargetkan penuntasannya pada tahun 2008. Akan tetapi dalam pelaksanaannya masih menemui banyak kendala, antara lain adalah faktor biaya, sarana persekolahan, dan keadaan yang mengharuskan anak didik bekerja, sehingga target penuntasan wajib belajar sembilan tahun secara keseluruhan belum tercapai. Khusus Provinsi DKI Jakarta program wajib belajar 9 tahun telah berhasil dituntaskan. Angka Partisipasi Kasar (APK) Sekolah Menengah Pertama Provinsi DKI Jakarta pada tahun 2004 telah mencapai 102,86\%, sedangkan untuk Sekolah Menengah mencapai 81,41\%. Berdasarkan fakta ini, seharusnya provinsi DKI Jakarta mulai meningkatkan kualitas pendidikan warganya dengan program wajib belajar 12 tahun. Hal ini sesuai dengan perkembangan kota Jakarta sebagai kota jasa yang sejajar dengan kota-kota besar lainnya di Asia, yang membutuhkan sumber daya manusia yang unggul dan tangguh dalam bidang industri jasa. Dalam rangka menuntaskan wajib belajar 12 tahun, masih dibutuhkan tambahan anggaran baik dari APBN, APBD maupun partisipasi masyarakat dan dunia usaha. Pembiayaan program wajib belajar 12 tahun, harus diarahkan pada pengelolaan dan pengawasan sumber daya pembiayaan dan peningkatan kualitas pendidikan.
\end{abstract}

Kata kunci: penuntasan wajib belajar sembilan tahun, APK dan APM, kualitas lulusan, perencanaan pembiayaan, manajemen strategis.

Abstract: Program nine years of compulsory education in Indonesia started launched in 1994 and finished in the year targeted 2008. However, in practice still have a lot of obstacles, among others, is the cost factor, the means of schooling, and the circumstances that require students to work, so that the target of completing the nine-year compulsory education as a whole have not been met. Special Province of DKI Jakarta program compulsory education of 9-year, has been successfully completed. Gross Enrollment Rate (GER) Junior High School for DKI Jakarta province in 2004 has reached $102.86 \%$, while for senior high school by $81.41 \%$. Based on these facts, it should provincial DKI Jakarta began improving education quality by improving citizens 12 years of mandatory programs. This is in accordance with the development of Jakarta as a city service that is parallel to the major cities the other in Asia, which requires human resources and strong excel in the service industry. In order for completing compulsory education reached 12 years, still required additional budget from the state budget, budget and community participation and the business world. Financing programs compulsory education to 12 -year, should be directed to the management and supervision of financial resources and improving the quality of education.

Key words: completion of nine-year compulsory education, GER and NER, the quality of graduates, financial planning, strategic management. 


\section{Pendahuluan}

Upaya peningkatan sumber daya manusia yang utama dilakukan melalui pembangunan sektor pendidikan, seperti yang dinyatakan oleh Becker bahwa pendidikan merupakan faktor yang penting dalam pengembangan sumber daya manusia. Pendidikan tidak saja menambah pengetahuan, akan tetapi juga meningkatkan keterampilan bekerja yang akhirnya akan meningkatkan produktivitas kerja (Becker, 1994). Pengalaman empiris telah membuktikan bahwa bangsa-bangsa yang telah menikmati kesejahteraan dan kemakmuran bagi rakyatnya adalah bangsa yang memulai pembangunannya melalui pendidikan meskipun tidak memiliki sumber daya alam. Dengan sumber daya manusia yang berkualitas serta menguasai ilmu pengetahuan dan teknologi, bangsa tersebut dapat menikmati kemakmuran bangsanya. Sebagai contoh adalah negaranegara seperti Jepang, Taiwan, Korea Selatan, dan Singapura.

Program wajib belajar sembilan tahun merupakan kebijakan pemerintah di dalam memperbaiki kualitas sumber daya manusia Indonesia agar memiliki standar pendidikan minimal sembilan tahun sebagai modal dasar pembangunan bangsa dalam meningkatkan pertumbuhan ekonomi melalui peningkatan produktivitas kerja tenaga terdidik di masa datang sekaligus mempersiapkan masyarakat agar mampu bersaing di pasar global. Program wajib belajar sembilan tahun didasari konsep "pendidikan dasar untuk semua"(universal basic education), yang pada hakekatnya berarti penyediaan akses yang sama untuk semua anak (Daliyo, 1998). Tujuan yang ingin dicapai dengan program ini adalah merangsang aspirasi pendidikan orang tua dan anak yang pada gilirannya diharapkan dapat meningkatkan produktivitas kerja penduduk secara nasional.

Pelaksanaan program wajib belajar sembilan tahun masih banyak menemui kendala, antara lain adalah faktor biaya, sarana persekolahan, keadaan geografis, ketidakmampuan mengikuti pelajaran, adanya larangan orang tua, dan keadaan yang mengharuskan anak didik bekerja. Menurut hasil Survei Sosial Ekonomi Nasional (Susenas) tahun 2003 yang dilaksanakan oleh Badan Pusat Statistik menyebutkan 67\% alasan masyarakat tidak bersekolah atau putus sekolah adalah ketiadaan biaya. Kesulitan ini bertambah dengan krisis yang melanda Indonesia sejak tahun 1997. Data tahun 1998-1999 menunjukkan bahwa terjadi peningkatan angka putus sekolah pada jenjang pendidikan dasar yang cukup signifikan. Pada jenjang sekolah dasar siswa yang potensial putus sekolah sebesar $5,7 \%$ dari sebelumnya $2,6 \%$ dan jenjang sekolah menengah pertama sebesar $11,5 \%$ dari sebelumnya $5,1 \%$ (Yahya, 2003).

Sesuai dengan hasil Susenas sebagian besar masyarakat tidak mengikuti kegiatan persekolahan karena tidak adanya biaya. Hal ini menunjukkan bahwa faktor biaya pendidikan merupakan unsur utama dalam penuntasan wajib belajar sembilan tahun dan peningkatan mutu pembelajaran. Padahal wajib belajar sembilan tahun juga merupakan amanat Undang-undang Nomor 20 Tahun 2003 tentang Sistem Pendidikan Nasional yang mewajibkan negara menanggung biayanya. Akan tetapi kenyataannya, anggaran untuk pendidikan dalam APBN 2006/2007 masih dirasakan kecil, sebab baru sekitar $8 \%$ dari $20 \%$ yang diamanatkan Undang-undang Sisdiknas. Meskipun dari dana kompensasi bahan bakar minyak (PKPS BBM) tahun 2005 pemerintah memberikan subsidi pada pendidikan dasar dan menengah sebesar 6,27 triliun, tetapi masih belum mencukupi apabila digunakan untuk penuntasan wajib belajar sembilan tahun dan peningkatan mutu pembelajaran.

Dari hasil perhitungan panitia anggaran Dewan Perwakilan rakyat bersama pemerintah diperoleh bahwa satuan biaya pendidikan untuk SD pada tahun 2005 adalah sebesar Rp. 235.000 per tahun per siswa, dan untuk SMP adalah Rp. 324.000 per tahun per siswa (www.kompas. co.id). Sedangkan hasil perhitungan Ghozali ratarata satuan biaya pendidikan di sekolah negeri untuk SD pada tahun 2004 adalah sebesar 1,864 juta per siswa per tahun, dan untuk SMP sebesar 2,771 juta per siswa per tahun (www.kompas. co.id). Terdapat selisih yang sangat besar di antara keduanya. Hal ini bisa terjadi karena masih adanya pungutan atau keperluan lain yang kurang diperhitungkan oleh DPR dan pemerintah, misalnya untuk honorarium guru dan kegiatan ekstrakurikuler. 
Program wajib belajar sembilan tahun juga menghadapi masalah kualitas pembelajaran. Kualitas pembelajaran ditunjukkan oleh mutu proses pembelajaran dan hasil pembelajaran yang dilaksanakan. Hasil penelitian Ghozali menunjukkan bahwa mutu proses pembelajaran pada pendidikan dasar dan menengah tergolong rendah. Sedangkan mutu hasil belajar siswa secara keseluruhan belum mencapai nilai rata-rata yang baik, karena masih di bawah nilai tujuh (Ghozali, 2005). Selain itu, masalah lainnya dalam kualitas pembelajaran adalah mutu guru. Saat ini hanya sekitar $50 \%$ guru pada pendidikan dasar yang memenuhi kualifikasi pendidikan strata satu (Harian Kompas, 29 November 2005). Dengan demikian secara nasional masih diperlukan banyak pembenahan dalam pelaksanaan program wajib belajar sembilan tahun. Kenyataan ini membuat pemerintah memundurkan target penuntasan program wajib belajar sembilan tahun dari tahun 2004 menjadi tahun 2008.

Akan tetapi kenyataan tersebut berbeda dengan yang terjadi Di Provinsi DKI Jakarta. Angka partisipasi kasar (APK) SMP untuk provinsi DKI Jakarta pada tahun 2004 telah mencapai 102,86\% (Harian Kompas, 29 November 2005), sedangkan untuk SLTA sebesar $81,41 \%$. APK SLTA kemudian meningkat menjadi $81,65 \%$ pada tahun 2006 (www.dikmentidki.go.id). Dengan keadaan seperti itu, pemerintah Provinsi DKI Jakarta sudah menuntaskan program wajib belajar 9 tahun. Oleh sebab itu perlu ditingkatkan menjadi program penuntasan wajib belajar 12 tahun. Dari uraian di atas maka diperlukan kajian yang meneliti penuntasan wajib belajar dua belas tahun di Provinsi DKI Jakarta, terutama yang terkait dengan pembiayaan dan mutu pembelajaran.

Masalah dalam kajian ini dirumuskan sebagai berikut: 1) Bagaimanakah perencanaan pembiayaan yang dilaksanakan dalam penuntasan wajib belajar 12 tahun di provinsi DKI Jakarta? 2) Bagaimanakah manajemen strategi yang diterapkan untuk menjaga mutu pembelajaran dalam rangka penuntasan wajib belajar 12 tahun di provinsi DKI Jakarta.

Tujuan kajian ini adalah dapat diperoleh data dan informasi tentang: 1) perencanaan pembiayaan yang dilaksanakan dalam penuntasan wajib belajar 12 tahun di provinsi DKI Jakarta, 2) manajemen strategi yang diterapkan untuk menjaga mutu pembelajaran dalam rangka penuntasan wajib belajar 12 tahun di provinsi DKI Jakarta.

\section{Kajian Literatur dan Pembahasan Program Wajib Belajar}

Program wajib belajar merupakan amanat Undang-Undang Dasar 1945 pasal 31 yang menyatakan bahwa setiap warga negara berhak memperoleh pendidikan, setiap warga negara wajib memperoleh pendidikan dasar dan pemerintah wajib menyediakan dananya. Hal ini diperkuat dengan Undang-Undang No. 20 Tahun 2003 tentang Sistem Pendidikan Nasional yang pada pasal 6 ayat 1 menyebutkan bahwa setiap warga negara yang berusia tujuh sampai dengan lima belas tahun wajib mengikuti pendidikan dasar. Selanjutnya pada pasal 17 ayat 2 dijelaskan bahwa yang dimaksud dengan pendidikan dasar adalah berbentuk sekolah dasar (SD) dan madrasah ibtidaiyah (MI) atau bentuk lain yang sederajat serta sekolah menengah pertama (SMP) dan madrasah tsanawiyah (MTs), atau bentuk lain yang sederajat.

Selain amanat Undang-undang, pada dasarnya program wajib belajar merupakan tuntutan perubahan karena didasari konsep "pendidikan dasar untuk semua"(universal basic education), yang pada hakekatnya berarti penyediaan akses yang sama untuk semua anak (Daliyo, 1998). Dengan penyediaan akses yang sama bagi semua anak, maka setiap anak akan memperoleh peningkatan kemampuan bersaing dalam iklim gobal, sebab peningkatan mutu SDM pada tingkat penguasaan pendidikan dasar merupakan persyaratan minimum bagi setiap warga negara Indonesia untuk mengenal peralatan elektronik, prinsip kerja mesin-mesin produksi dan pertanian, alat-alat rumah tangga yang diperlukan untuk membangun kehidupan modern dengan menggunakan teknologi dasar. Dengan demikian program wajib belajar bertujuan untuk memberikan bekal kemampuan dasar kepada peserta didik untuk mengembangkan kehidupannya sebagai pribadi, anggota masyarakat, warga negara dan anggota umat manusia serta mempersiapkan peserta didik untuk mengikuti pendidikan menengah. 
Hal ini sejalan dengan komitmen Negaranegara PBB untuk Education for All (EFA) di Jomtien tahun 1991 dan Dakar tahun 2000 berisikan enam tujuan utama, yaitu: (1) memperluas pendidikan untuk anak usia dini, (2) menuntaskan wajib belajar untuk semua pada tahun 2015, (3) mengembangkan proses pembelajaran/keahlian untuk orang muda dan dewasa, (4) meningkatnya $50 \%$ orang dewasa yang melek huruf pada tahun 2015, khususnya perempuan, (5) menghapuskan kesenjangan gender, dan (6) meningkatkan mutu pendidikan (Muchtar, 2004). Komitmen ini tentunya juga mengikat Indonesia sebagai negara anggota PBB.

Program wajib belajar sembilan tahun di Indonesia di mulai pencanangannya pada tahun 1994 dan ditargetkan penuntasannya pada tahun 2008 (Harian Kompas, 29 November 2005). Ada lima alasan bagi pemerintah untuk memulai program wajib belajar sembilan tahun: (1) lebih dari 80 persen angkatan kerja hanya berpendidikan SD atau kurang, atau SMP tidak tamat; (2) program wajib belajar sembilan tahun akan meningkatkan kualitas SDM dan dapat memberi nilai tambah pada pertumbuhan ekonomi; (3) semakin tinggi pendidikan akan semakin besar partisipasi dan kontribusinya di sektor-sektor yang produktif; (4) dengan peningkatan program wajib belajar dari enam ke sembilan tahun, akan meningkatkan kematangan dan ketrampilan siswa; (5) peningkatan wajib belajar menjadi sembilan tahun akan meningkatkan umur kerja minimum dari 10 ke 15 tahun (Daliyo, 1998). Jadi suksesnya pelaksanaan wajib belajar sembilan tahun akan meningkatkan produktivitas kerja manusia Indonesia secara keseluruhan.

Akan tetapi pencapaian program wajib belajar sembilan tahun oleh pemerintah belum mencapai hasil maksimal sehingga target pencapaian penuntasan wajib belajar sembilan tahun pada tahun 2008 masih merupakan pekerjaan yang berat bagi pemerintahan di orde reformasi ini. Indikator- pencapaian program wajib belajar sembilan tahun adalah kinerja pencapaian Angka Partisipasi Kasar (APK) dan Angka Partisipasi Murni (APM) untuk jenjang pendidikan SD sampai SMP sebesar 90\% (Bank Dunia, 2004). Angka Partisipasi Kasar (APK) adalah persentase jumlah siswa seluruhnya terhadap jumlah penduduk usia sekolah pada jenjang tertentu. APK dihitung dengan rumus:

(Jumlah siswa seluruhnya)

APK $=\frac{}{\text { (Jumlah penduduk usia 7-15) }} \times 100 \%$

Angka Partisipasi Murni (APM) adalah persentase jumlah siswa usia sekolah terhadap jumlah penduduk usia sekolah pada suatu jenjang sekolah, usia sekolah pendidikan dasar adalah 715 Tahun. Besarnya APM dihitung dengan rumus:

(Jumlah siswa usia 7-15)

$\mathrm{APM}=$ X $100 \%$

(Jumlah penduduk usia 7-15)

(sumber: www.depdiknas.go.id/ditjen manajemendikdasmen)

Berdasarkan laporan Bank Dunia tahun 2004 Indonesia masih belum mampu memenuhi program wajib belajar sembilan tahun bagi semua anak, karena masih terdapat sekitar 20 persen anak usia sekolah menengah pertama yang masih belum bersekolah (Bank Dunia, 2004). Krisis ekonomi yang melanda Indonesia berpengaruh terhadap APK dan APM pendidikan dasar. Pada tahun 1998 meskipun APK dan APM SD+MI secara nasional telah tuntas yaitu masing-masing sebesar 113,74\% dan 93,74\%, namun untuk SLTP+MTs masih jauh dari tuntas, yaitu sebesar $71,92 \%$ dan 55,05\% (www.depdiknas.go.id/ ditjenmanajemendikdasmen).

Keadaan menjadi sangat ironis bila dibandingkan dengan kondisi negara pesaing Indonesia di Asia Tenggara, seperti Thailand dan Malaysia. Tahun 2003, Thailand telah memperluas wajib belajar 9 tahun menjadi 12 tahun dan mulai mempersiapkan kebijakan wajib belajar 15 tahun secara gratis, sementara Malaysia mentargetkan angka partisipasi di universitas mencapai $40 \%$ pada tahun 2010 (www.economist.com). Rencana ini tentu akan meninggalkan Indonesia jauh di belakang dalam rata-rata lama sekolah para tenaga kerjanya.

Dengan merujuk indikator pencapaian program wajib belajar sembilan tahun, secara 
nasional Indonesia telah mencapai hasil-hasil seperti dalam tabel berikut:

Tabel 1. Pencapaian Program Wajib Belajar 9 Tahun Nasional Tahun 2003/2004.

\begin{tabular}{|c|c|c|c|}
\hline \multirow{2}{*}{ No. } & Indikator & \multicolumn{2}{|c|}{ Pencapaian (\%) } \\
\cline { 3 - 4 } & & SD+MI & SMP+MTs \\
\hline 1. & Angka Partisipasi Kasar (APK) & 114,88 & 81,65 \\
\hline 2. & Angka Partisipasi Murni (APM) & 94,00 & 61,60 \\
\hline
\end{tabular}

Sumber: Bank Dunia "Indonesia Policy Briefs" Tahun 2004.

Dari data tersebut terlihat keadaan yang memprihatinkan pada APK dan APM SMP yang baru mencapai masing-masing $81,65 \%$ dan $61,60 \%$. Akan tetapi keadaan tersebut berbeda untuk provinsi DKI Jakarta. Pencapaian program wajib belajar di provinsi DKI Jakarta pada tahun 2004 memuaskan. APK untuk SMP sudah mencapai ketuntasan yaitu sebesar 102,86\% dan APM nya $91,20 \%$ (www.depdiknas.go.id/statistik pendidikan). Terlihat bahwa APK dan APM untuk jenjang SMP di provinsi DKI Jakarta di atas rata-rata nasional.

Keadaan itu bisa dicapai karena pemerintah provinsi DKI Jakarta telah memberikan anggaran untuk pendidikan dengan porsi yang besar. Dari APBD Provinsi DKI Jakarta tahun 2008 anggaran pendidikan dialokasikan sebesar 5,25 Trilyun atau sebesar 25,61\% dari total APBD sebesar 20,5 Trilyun. Bahkan untuk mencapai program wajib belajar sembilan tahun, mulai tahun 2005 Pemprov DKI Jakarta telah memberikan pendidikan gratis bagi siswa sampai tingkat SMP.

Berdasarkan kenyataan di atas, maka sudah selayaknya pemprov DKI Jakarta mulai meningkatkan kualitas pendidikan warganya dengan meningkatkan program wajib belajar dua belas tahun. Hal ini sesuai dengan pengembangan kota Jakarta sebagai kota jasa yang sejajar dengan kota-kota besar lainnya di Asia yang menuntut sumber daya manusia yang unggul dan tangguh dalam bidang industri jasa.

\section{Perencanaan Pembiayaan Program Wajib Belajar Dua Belas Tahun}

Pencapaian ketuntasan program wajib belajar dua belas tahun yang diikuti dengan peningkatan mutu proses dan hasil pembelajaran pendidikan dasar memerlukan pembiayaan yang cukup besar. Meskipun manajemen strategi yang dikembangkan dan kemudian siap diimplementasikan dinilai telah cukup baik, tetapi tanpa dukungan dana yang memadai maka agenda itu akan menjadi sia-sia.

Pembiayaan pendidikan untuk pendidikan dasar dan menengah memiliki cakupan yang luas yakni semua pengeluaran yang diperlukan untuk penyelenggaraan pendidikan dasar (Supriadi, 2003). Biaya tersebut oleh Ghozali (2005) digolongkan menjadi tiga tingkatan yaitu biaya di tingkat orangtua/siswa, tingkat sekolah, dan tingkat wilayah atau pusat. Biaya tingkat orangtua/siswa adalah seluruh biaya pribadi orangtua/siswa yang dipergunakan untuk bersekolah seperti biaya transport, uang iuran sekolah, kebutuhan buku dan alat tulis, dan uang saku. Biaya tingkat sekolah adalah biaya yang diperlukan sekolah untuk melaksanakan kegiatankegiatan pembelajaran. Termasuk di dalamnya adalah gaji guru/pegawai sekolah, bahan ajar, sarana, kegiatan pembelajaran dan penilaian. Sedangkan biaya tingkat wilayah/pusat adalah biaya yang diperlukan oleh dinas pendidikan/ departemen pendidikan untuk mengelola persekolahan, khususnya sekolah tingkat dasar.

Pada tingkat satuan pendidikan biaya pendidikan diperoleh melalui subsidi pemerintah pusat, pemerintah daerah, iuran siswa, dan sumbangan masyarakat (Supriadi, 2003). Subsidi pemerintah dianggarkan untuk bantuan operasional sekolah melalui APBN/APBD maupun subsidi lainnya, seperti subsidi dari kenaikan harga bahan bakar minyak. Pendapatan sekolah dianggarkan melalui APBS dan sumbangan masyarakat baik bersifat perorangan maupun dari organisasi atau perusahaan.

Penggunaan biaya pendidikan oleh UNDP (2004) dikategorikan untuk biaya peningkatan kualitas, peningkatan pemerataan, dan manajemen pendidikan. Pada tingkat pendidikan dasar nilainya mencapai Rp. 1.174 .700 perorang pertahun. Sedangkan berdasarkan hasil 
penelitian Ghozali rata-rata biaya satuan pendidikan persiswa pertahun untuk SD mencapai Rp. 1.864.000 dan SMP mencapai Rp. 2.771.000 (www.kompas.co.id). Bila melihat nilai sebesar itu, pendidikan dasar di Indonesia masih terasa mahal jika dibandingkan penghasilan orang miskin yang perharinya hanya kurang lebih Rp. 20.000, sementara bantuan biaya dari pemerintah sebagai akibat kenaikan harga BBM baru mencapai Rp. 235.000 untuk tingkat SD dan Rp. 324.000 untuk tingkat SMP (Harian Kompas, 27 Juni 2005).

Demikian halnya pendidikan pada tingkat sekolah menengah (SM). Menurut Ghozali (2005) biaya pendidikan perorang pertahun di SMA sebesar Rp. Rp. 3.612.000 dan SMK Rp. 4.737.000. Sementara untuk jenjang pendidikan SM tidak ada bantuan operasional sekolah (BOS) seperti pada SD dan SMP, padahal jumlah orang miskin di Indonesia sudah mencapai 40 juta orang.

Besarnya biaya pendidikan, terutama pada tingkat satuan pendidikan menurut Supriadi (2003), berhubungan dengan berbagai indikator mutu pendidikan, seperti angka partisipasi, angka putus sekolah, dan prestasi belajar siswa. Oleh sebab itu, dalam konteks perencanaan pembiayaan pendidikan, pemahaman terhadap berbagai aspek pembiayaan pendidikan sangat penting. Pemahaman tersebut dari hal-hal yang sifatnya mikro pada satuan pendidikan hingga yang makro secara nasional, antara lain meliputi sumber-sumber pembiayaan pendidikan, sistem dan mekanisme pengalokasiannya, efektivitas dan efsiensi dalam penggunaannya, dan akuntabilitas hasilnya yang diukur dari perubahan-perubahan kuantitatif dan kualitatif yang terjadi pada semua tataran, khususnya di tingkat sekolah.

Dengan demikian pembiayaan program wajib belajar dua belas tahun diarahkan pada pengelolaan dan pengawasan sumber daya pembiayaan pendidikan yang diperlukan untuk penuntasan program wajib belajar sembilan tahun dan peningkatan mutu pendidikan. Pengelolaan menyangkut distribusi, efektivitas dan efisiensi sumber dana dan pengawasan adalah berjalannya fungsi-fungsi kontrol baik secara internal maupun eksternal dalam pembiayaan pendidikan dasar dan menengah di provinsi DKI Jakarta.

\section{Manajemen Strategi Mutu Wajib Belajar 12 Tahun}

Program wajib belajar dua belas tahun adalah bagian dari upaya peningkatan mutu pendidikan. Selain pencapaian target penuntasan APK dan APM, pendidikan dasar dan menengah masih memiliki banyak masalah yang terkait dengan mutu proses dan hasil pembelajaran. Proses dan hasil pembelajaran dinilai dari kinerja pelayanan yang diberikan oleh satuan pendidikan kepada peserta didik. Tola dan Furqon (2003) menyatakan bahwa mutu pembelajaran dan hasil belajar yang memuaskan merupakan produk akumulatif dari seluruh layanan yang dilakukan sekolah dan pengaruh dari suasana/iklim yang kondusif yang diciptakan di sekolah. Selanjutnya Levine (1994) menyatakan bahwa sekolah yang efektif menunjukkan tingkat kinerja yang diharapkan dalam menyelenggarakan proses belajarnya, dengan menunjukkan hasil belajar yang bermutu pada peserta didik sesuai dengan tugas pokoknya. Esensi pernyataan tersebut adalah menunjukkan bahwa sekolah berfungsi sebagai tempat belajar yang memiliki kewajiban untuk menyelenggarakan pengalaman pembelajaran yang bermutu bagi peserta didiknya.

Sekolah sebagai sistem harus menekankan proses belajar mengajar sebagai "pemberdayaan" pelajar, yang dilakukan melalui interaksi perilaku pengajar dan perilaku pelajar, baik di ruang maupun diluar kelas. Karena proses belajar mengajar merupakan pemberdayaan pelajar, maka penekanannya bukan sekadar mengajarkan sesuatu kepada pelajar, melainkan proses belajar mengajar yang mampu menumbuhkan daya kreasi, daya nalar, rasa keingintahuan, dan eksperimentasi untuk membuka dan menemukan kemungkinan-kemungkinan baru, menumbuhkan demokrasi, memberikan kemerdekaan, dan memberikan toleransi terhadap kekeliruankekeliruan akibat kreativitas berfikir (Bakrie, 1999). Proses belajar mengajar dapat digambarkan sebagai berikut: 


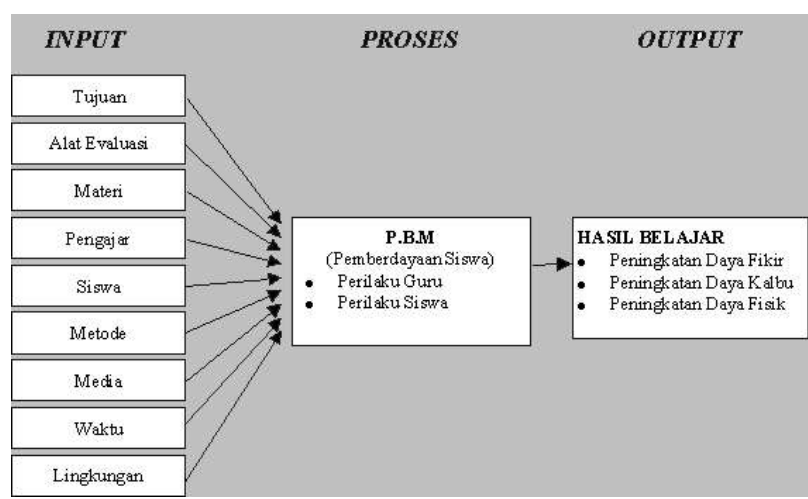

(Sumber: Slamet PH. 2000. Karakteristik Kepala Sekolah Tangguh. www:depdiknas.go.id/balitbang/ publikasi)

Dari gambar tersebut terlihat bahwa faktorfaktor yang mempengaruhi proses belajar mengajar adalah tujuan pembelajaran, alat evaluasi, materi, pengajar, siswa, metode, media, waktu, dan lingkungan. Hal yang sejalan dinyatakan oleh Sudjana (1995) yang menyebutkan bahwa komponen pengajaran sebagai dimensi penilaian proses belajar-mengajar mencakup tujuan pengajaran (kurikulum), bahan pengajaran, siswa, guru, alat dan sumber belajar, dan penilaian. Meskipun faktor-faktor tersebut merupakan komponen kinerja pelayanan pada tingkat satuan pendidikan, akan tetapi pengelolaan satuan pendidikan adalah tanggung jawab dinas pendidikan di daerah maupun pemerintah pusat. Oleh sebab itu agar proses pembelajaran dapat berlangsung secara optimal, maka faktor-faktor tersebut menjadi titik fokus dalam pengelolaan pendidikan baik di tingkat satuan pendidikan, dinas pendidikan daerah maupun pemerintah pusat.

Pada tingkat pendidikan dasar faktor-faktor yang mempengaruhi kualitas proses pembelajaran masih dirasakan kurang memenuhi kebutuhan. Misalnya untuk faktor alat dan sumber belajar berupa sarana sekolah, masih terdapat 105.000 kelas yang rusak, banyak kelas kekurangan buku, dan masih banyak guru yang memiliki pendidikan tidak memadai (mismatch) (Harian Kompas, 29 November 2005). Di provinsi DKI Jakarta pada tahun ajaran 2006/2007 untuk SMA menunjukkan rasio ruang belajar/murid $1: 33$, untuk SMK 1:37. Rasio guru murid SMA 1:11 dan SMK 1:12 (www.dikmentidki.go.id/datapokok pendidikan2006/2007). Fakta ini ini membuktikan bahwa proses belajar-mengajar yang berlangsung di sekolah di provinsi DKI Jakarta sudah baik.

Selain itu mutu pendidikan sangat ditentukan oleh mutu hasil pembelajaran. Mutu hasil pembelajaran ditunjukkan oleh pencapaian hasil belajar siswa, angka lulusan, mengulang, dan putus sekolah. Di Provinsi DKI Jakarta angka Iulusan untuk SMA pada tahun 2005/2006 mencapai 99,44\%, sementara di SMK mencapai 98,55\% (www.depdiknas.go.id/statistikpendidikan). Kondisi ini sudah baik, namun masih diperlukan manajemen strategi yang handal dalam mengelola pendidikan menengah di provinsi DKI Jakarta.

Manajemen strategi peningkatan mutu pendidikan saat ini lebih berorientasi pada sekolah. Strategi ini berbeda dengan konsep mengenai pengelolaan sekolah selama ini. Dalam sistem lama, birokrasi pusat sangat mendominasi proses pengambilan atau pembuatan keputusan pendidikan, yang bukan hanya kebijakan bersifat makro saja tetapi lebih jauh kepada hal-hal yang bersifat mikro; Sementara sekolah cenderung hanya melaksanakan kebijakan-kebijakan tersebut yang belum tentu sesuai dengan kebutuhan belajar siswa, lingkungan Sekolah, dan harapan orang tua. Pengalaman menunjukkan bahwa sistem lama seringkali menimbulkan kontradiksi antara apa yang menjadi kebutuhan sekolah dengan kebijakan yang harus dilaksanakan di dalam proses peningkatan mutu pendidikan. Hal inilah yang kemudian mendorong munculnya pemikiran untuk beralih kepada konsep manajemen peningkatan mutu berbasis sekolah sebagai pendekatan baru di Indonesia, yang merupakan bagian dari desentralisasi pendidikan yang tengah dikembangkan.

Konsep ini diperkenalkan oleh teori effective school yang lebih memfokuskan diri pada perbaikan proses pendidikan. Beberapa indikator yang menunjukkan karakter dari konsep manajemen ini menurut Umaedi (1999) antara lain sebagai berikut; (i) lingkungan sekolah yang aman dan tertib, (ii) sekolah memiliki misi dan target mutu yang ingin dicapai, (iii) sekolah memiliki kepemimpinan yang kuat, (iv) adanya harapan yang tinggi dari personel sekolah (kepala sekolah, guru, dan staf lainnya termasuk siswa) untuk 
berprestasi, ( $v$ ) adanya pengembangan staf sekolah yang terus menerus sesuai tuntutan IPTEK, (vi) adanya pelaksanaan evaluasi yang terus menerus terhadap berbagai aspek akademik dan administratif, dan pemanfaatan hasilnya untuk penyempurnaan/perbaikan mutu, dan (vii) adanya komunikasi dan dukungan intensif dari orang tua murid/masyarakat. Meskipun peningkatan mutu pendidikan ditekankan berbasis sekolah, tetapi pengembangan konsep manajemen ini didesain untuk meningkatkan kemampuan sekolah dan masyarakat dalam mengelola perubahan pendidikan kaitannya dengan tujuan keseluruhan, kebijakan, strategi perencanaan, inisiatif kurikulum yang telah ditentukan oleh pemerintah dan otoritas pendidikan.

Dalam uraian di atas telah disebutkan bahwa mutu proses pembelajaran ditentukan dari terselenggaranya secara optimal komponenkomponen pembelajaran berupa kurikulum, siswa, guru, alat dan sumber belajar. Kemudian mutu hasil pembelajaran ditentukan dari pencapaian hasil belajar siswa, angka kelulusan, angka mengulang, dan angka putus sekolah. Sementara itu manajemen strategi diartikan sebagai penetapan dan pengelolaan fungsi-fungsi manejemen berdasarkan analisis internal dan eksternal dalam sebuah organisasi. Fungsi-fungsi manajemen tersebut adalah perencanaan, pengorganisasian, pelaksanaan, dan pengawasan.

Dengan demikian manajemen strategi peningkatan mutu wajib belajar 12 tahun merupakan kualitas penetapan dan pengelolaan fungsi-fungsi manajemen berupa perencanaan, pengorganisasian, pelaksanaan, dan pengawasan berdasarkan analisis internal dan eksternal yang dilakukan oleh dinas pendidikan pemerintah daerah provinsi DKI Jakarta untuk mendukung terlaksananya manajemen peningkatan mutu berbasis sekolah (MPMBS), dalam rangka peningkatan komponen kurikulum, siswa, guru, alat dan sumber belajar, pencapaian hasil belajar siswa, dan angka kelulusan, serta penurunan angka mengulang, dan angka putus sekolah pada tingkat pendidikan dasar dan menengah.

\section{Simpulan dan Saran}

\section{Simpulan}

Dari hasil analisis pemaparan, maka disimpulkan beberapa hal sebagai berikut. Pertama, perencanaan pembiayaan untuk pelaksanaan wajib belajar 12 tahun di provinsi DKI Jakarta dapat dipenuhi mengingat anggaran bidang pendidikan di provinsi DKI Jakarta cukup besar. Namun pembiayaan itu porsinya lebih besar untuk penuntasan wajib belajar di pendidikan dasar. Agar penuntasan wajib belajar 12 tahun tercapai, masih diperlukan anggaran tambahan baik dari APBN, APBD maupun partisipasi masyarakat dan dunia usaha. Pembiayaan program wajib belajar dua belas tahun juga harus diarahkan pada pengelolaan dan pengawasan sumber daya pembiayaan dan peningkatan mutu pendidikan. Pengelolaan menyangkut distribusi, efektivitas dan efisiensi sumber dana. Pengawasan adalah berjalannya fungsi-fungsi kontrol baik secara internal maupun eksternal dalam pembiayaan pendidikan di provinsi DKI Jakarta. Kedua, manajemen strategi yang diterapkan dalam menjaga mutu pembelajaran sudah baik. Ini terbukti dengan rasio sarana yang baik untuk murid dan tingginya tingkat kelulusan siswa SMA/ SMK di Provinsi DKI Jakarta. Akan tetapi dalam rangka penuntasan wajib belajar 12 tahun diperlukan kebijakan yang akurat dalam menetapkan dan mengelola fungsi-fungsi manajemen berupa perencanaan, pengorganisasian, pelaksanaan, dan pengawasan berdasarkan analisis internal dan eksternal yang dilakukan oleh dinas pendidikan menengah tinggi provinsi DKI Jakarta. Hal itu untuk mendukung terlaksananya manajemen peningkatan mutu berbasis sekolah (MPMBS) dalam rangka peningkatan komponen kurikulum, siswa, guru, alat dan sumber belajar, pencapaian hasil belajar siswa, dan angka kelulusan, serta penurunan angka mengulang dan angka putus sekolah.

\section{Saran}

Pertama, untuk mengurangi angka putus sekolah dan pemerataan mutu pendidikan di SMA/SMK dapat dilakukan dengan subsidi yang berbeda antara sekolah satu dengan yang lainnya. Saat ini di provinsi DKI Jakarta sekolah gratis baru dilaksanakan sampai tingkat SMP. Oleh sebab itu 
kebijakan ini perlu diperluas sampai SM, namun dengan perlakuan yang berbeda. Untuk sekolah favorit dan kaya, tidak diperlakukan sama dengan sekolah miskin. Pada sekolah mampu/mandiri, siswa diberikan subsidi biaya pendidikan yang sama dengan siswa dari sekolah tidak mampu, tetapi kebutuhan fasilitas lainnya hanya diberikan pemerintah kepada sekolah tidak mampu. Deskripsinya adalah sebagai berikut: misalkan biaya iuran pendidikan siswa SMA perorang pertahun adalah sebesar Rp. 3.000.000, jika suatu sekolah memiliki 500 orang siswa, maka besarnya subsidi dari pemerintah adalah Rp. 3.000.000 x $500=$ Rp. 1.500.000.000. Subsidi ini di luar gaji guru dan biaya rutin sekolah (mis: Telepon, Listrik, dan Air). Hal ini berlaku untuk semua sekolah, akan tetapi bagi sekolah mampu masih diperbolehkan meminta bantuan komite sekolah/orang tua siswa untuk memenuhi kebutuhan fasilitas sekolahnya. Sementara untuk sekolah tidak mampu, kebutuhan fasilitas masih dipenuhi lagi oleh pemerintah hingga mencapai standar sekolah yang maju. Orangtua atau masyarakat berperan membantu pengembangan sekolah mencapai standar pelayanan pendidikan yang bermutu. Kategori kemampuan sekolah antara lain dapat dilihat dari prosentase pencapaian sumbangan dari komite/orang tua dalam memenuhi anggaran dan pendapatan sekolah (APBS). Kedua, melanjutkan pembangunan unit sekolah baru (USB) dan ruang kelas baru (RKB). Dalam pembangunan USB/RKB, pemetaan sekolah (school mapping) hendaknya menjadi perhatian utama serta tetap memberi perhatian dan bantuan kepada sekolah-sekolah swasta yang membutuhkan. Ketiga, melanjutkan program jaring pengaman sosial di bidang pendidikan melalui program pemberian beasiswa bagi siswa yang kurang mampu, serta pemberian dana bantuan operasional (DBO) bagi sekolah-sekolah yang berada di kantong-kantong masyarakat miskin. Masih terjadi siswa putus sekolah bukan karena biaya sekolah, tetapi masalah ekonomi keluarganya atau ketiadaan sarana untuk transportasi ke sekolah. Keempat, memberdayakan dan meningkatkan mutu SLTP/SLTA Terbuka yang telah dikembangkan pada tahuntahun sebelumnya. Hal ini dilakukan melalui konsolidasi dan perbaikan manajemen kelembagaan, peningkatan kualitas guru bina dan pamong, perbaikan mutu buku modul, perbaikan proses belajar mengajar, dan peningkatan dukungan dan kerjasama dengan masyarakat. Kelima, melanjutkan pengadaan buku mata pelajaran yang berkualitas sehingga rasio buku dan murid mencapai 1:1 untuk setiap mata pelajaran. Oleh karena itu, berbagai kegiatan pokok perlu diperhatikan antara lain perbaikan/ revisi buku teks, pengadaan buku berdasarkan analisis kebutuhan atau permintaan sekolah, dan pemberian grant untuk pembelian buku sehingga sekolah mendapatkannya secara tepat jumlah dan tepat waktu.

\section{Pustaka Acuan}

Bakrie, Aburizal. 1999. Mengefektifkan Sistem Pendidikan Ganda. Makalah Disampaikan pada Rapat Kerja Majelis Pendidikan Kejuruan Nasional, Tanggal 29 Maret 1999 di Jakarta.

Becker, Gary S. 1994. Human Capital. Chicago: The University of Chicago Press.

Daliyo et. al. 1998. Pekerja Anak dan Perencanaan Pendidikan di Nusa Tenggara Barat dan Timur, Policy Paper No. 7. Jakarta: AisAID.

Ghozali, Abbas. 2005. Analisis Biaya Satuan Pendidikan Dasar dan Menengah, Laporan Penelitian. Jakarta: Balitbang Depdiknas.

Levine, M (Ed.). 1994. Professional Practices Schools. New York: Teachers College Press. Muchtar, Yanti. 2004. Capaian MDGs untuk Goal Pendidikan? Jakarta: Yayasan Kapal Perempuan. Slamet PH. 2000. Karakteristik Kepala Sekolah Tangguh. www:depdiknas.go.id/balitbang/publikasi Sudjana, Nana. 1995. Penilaian Hasil dan Proses Belajar Mengajar. Bandung: P.T. Remadja Rosdakarya. Supriadi, Dedi. 2003. Satuan Biaya Pendidikan Dasar dan Menengah. Bandung: PT. Remaja Rosdakarya. 
Tola, Burhanuddin dan Furqon. 2003. Pengembangan Model Penilaian Sekolah Efektif. www:depdiknas.go.id/publikasi/jurnal pendidikan.

Umaedi. 1999. Manajemen Peningkatan Mutu Berbasis Sekolah. www.depdiknas.go.id/publikasi.

Batu Ujian bagi Pemerintahan SBY-JK. Kompas, 29 November 2005.

Dana Kompensasi BBM Disepakati Biaya Pendidikan Dasar Dijamin Gratis. www.kompas.co.id . 2005

Biaya Pendidikan Lebih Banyak Ditanggung Orang tua Siswa. www.kompas.co.id. 2004.

Glosari Pendidikan. www.depdiknas.go.id./Ditjen Manajemen Dikdasmen.2003.

Pelaksanaan Wajib Belajar Pendidikan Dasar 9 Tahun. www.depdiknas.go.id/ditjen dikdasmen. 2003.

Negara Pesaing Indonesia telah Melangkah Lebih Jauh. www.economist.com. 2003.

Peningkatan Kualitas Pendidikan. www:cbe.org.id/Bank Dunia. 2004.

Indonesia Human Development Report. www.bappenas.go.id/UNDP. 2004.

www.depdiknas.go.id/statistik pendidikan

www.dikmentidki.go.id/data pokok pendidikan. 